\title{
Mineralogical, Geochemical and Distribution Study of Bauxites in the Locality of Bangam and Environs (West Cameroon)
}

\author{
Taylor Moise Sojien ${ }^{1}$, Estelle Lionelle Tamto Mamdem², Armand Sylvain Ludovic Wouatong ${ }^{3} \&$ Dieudonne \\ Lucien Bitom ${ }^{4}$ \\ ${ }^{1}$ Department of Earth Sciences, Faculty of sciences, university of Dschang, P.O. Box 67 Dschang, Cameroon \\ 2 Department of Earth Sciences, Faculty of sciences, university of Ngaoundéré P.O. Box 454 Ngaoundéré, \\ Cameroun \\ ${ }^{3}$ Department of Earth Sciences, Faculty of sciences, university of Dschang, P.O. Box 67 Dschang, Cameroon \\ ${ }^{4}$ Department of Earth Sciences, Faculty of sciences, university of Yaoundé 1 P.O. Box 812 Yaoundé, Cameroon \\ Correspondence: Armand Sylvain Ludovic Wouatong, Department of Earth Sciences, Faculty of Science, \\ University of Dschang, P.O Box 67 Dschang, Cameroon. E-mail: moisesojien1@gmail.com, \\ lionellemamdem@yahoo.fr, aslwouat@yahoo.com,dbitom@yahoo.fr
}

Received: December 15, 2017

Accepted: December 26, 2017 Online Published: January 23, 2018

doi:10.5539/esr.v7n1p117

URL: https://doi.org/10.5539/esr.v7n1p117

\begin{abstract}
The bauxite duricrust in the Bangam and surroundings is classified into three major storey levels as follows: the upper level on top of the plateaus where the continuous bauxites outcrop in slabs over distances of about $1 \mathrm{~km}$, the intermediate level on top and at the flanks of the hills where the bauxites flush in metric blocks, the lower level at the talwegs where bauxites duricrust are gravels. The average thickness of the duricrust is $9.6 \mathrm{~m}$ and extends over an area of about $9.5 \mathrm{~km}^{2}$. Five types of facies are encountered here: nodular, pisolitic, pseudobreccia, vacuolar and massive. These different facies were carried out by X-ray fluorescence spectrometry, X-ray diffractometric, thermal analysis (ATD / ATG) and by polarizing microscope observation. The results of these analyses show that, gibbsite is the dominant mineral; kaolinite, anatase, hematite, goethite, magnetite and ilmenite are also present. The chemical composition of the major elements that characterize bauxites are $38-60 \% \mathrm{Al}_{2} \mathrm{O}_{3} ; 2-22 \% \mathrm{SiO}_{2}$ and $9-42 \% \mathrm{Fe}_{2} \mathrm{O}_{3}$. These values are almost similar to those obtained in Doumbouo-Fokoué, Ghana, Ngaoundal, and Minim-Martap precisely at Briskok prospect. The different minerals paragenesis and geochemistry data show that, the Bangam locality is a bauxite ore deposit in spite of a high content of iron and silicate of some facies, nevertheless, these can be used in some industries.
\end{abstract}

Keywords: Bangam, bauxites, facies, gibbsite

\section{Introduction}

Bauxites are residual rocks (laterites and karst bauxites) containing at least $40 \% \mathrm{Al}_{2} \mathrm{O}_{3}$, less than $10 \% \mathrm{SiO}_{2}$ and $20 \%$ $\mathrm{Fe}_{2} \mathrm{O}_{3}$ (Bardossy \& Aleva 1990) and are recognized as the main supplier of aluminium. The study of bauxites in tropical regions has already been the subject of several scientific studies by authors such as Eno Belinga (1972), Nyobé (1987) and Momo et al (2012) for Cameroonian bauxites; Boulangé (1984) for Ivorian bauxites and Lucas et al. (1989) in Brazil. It began in the early 20th century and focused on the characterization and evaluation of well-known indices. At Minim-Martap and Ngaoundal, the contents of Alumina and Silica are $43 \%$ and $4 \%$ respectively. In Fongo-Tongo, the alumina contents range between $40-53 \%$ and $7 \%$ silica. In Dounbouo-Fokoué, we have $47.5-49.5 \%$ alumina and $7.6 \%$ silica. These datas indicate that Cameroon has the third bauxitic reserve in the world with approximately 1.5 billion tons, this amount seems to underestimate some unexplored areas where there are also bauxite indices in Cameroon SABAP exploration (Weeksteen.1957) and the recent geological map of Cameroon (Ntep, 2009). The locality of Bangam makes from these unexplored areas where one also encounters bauxites indices. The main objective of this study is to explore the Bangam locality, characterize the bauxites indices found there and compare it with others Cameroonians and Africans bauxites.

\section{Location of Study Area and Geological Setting}

The locality of Bangam and its surroundings are located in zone 32N 636000.651000 and 597500.587000 (see figure.1). It is subjected to a pseudo-equatorial climate (Dongmo, 1981) with four seasons (Melingui et al., 1989). 
The wet savannah is the type of vegetation encountered in Bangam (Letouzey, 1985). On the morphological level, hills and plateaus are found, which have average altitudes between $1170-1780 \mathrm{~m}$. The slopes are steep and slightly inclined, separated by convexo-concave interfluves. On the geological plan, our study area is an integral part of the Cameroon line (Deruelle et al. 1991) which crosses the western part of the Cameroonian territory. One encounters the volcanics rocks are aphyrics and porphyrics basalts mainly composed of plagioclase (andesine) rods, fine pyroxene grains (enstatite-augite), olivine and iron and titanium oxides are present as accessory minerals (Hieronymus, 1973). Dating from Neoprotorozoic to Cenozoic, the Panafrican is marked here by the presence of metamorphic rocks (Kwekam, 2005) such as biotite gneisses and weakly mylonitized gneisses (Fozing, 2009).

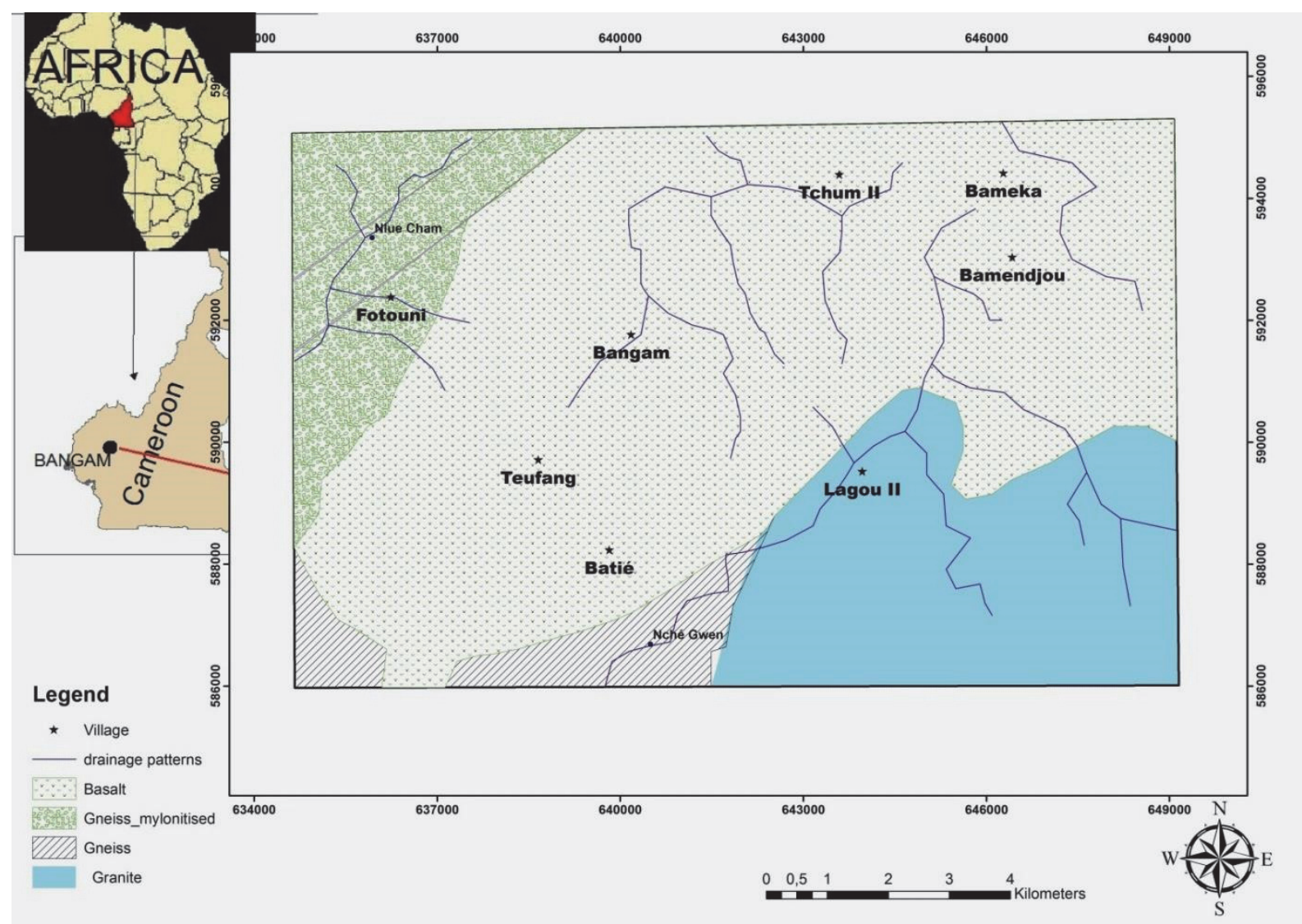

Figure 1. Location and geological Map of Bangam in the west-Cameroon region

\section{Materials and Methods}

The study of bauxites in Bangam was carried out at the scale of the landscape, microscopic, mineralogical, physical and geochemical, on different facies taken from every profile of the study area.

The study at the scale of the landscape made it possible to show the distribution of the bauxites from the previous works. It consisted in producing a bauxite distribution map from the Geographic Information System (GIS), which highlighted the different geomorphologic details of the study area. The mapping consisted of recording the data in the field using a GPS on areas of potential mineralization.

The alteration coat was studied on wells dug by picks and shovels on the tops and sides of the hills. The description of the different horizons was based on the soil description guide proposed by Maignien (1980), which consisted of a detailed study of the soil horizons and taking a sample at the surface for laboratory analyses.

Laboratory analyses were microscopic, physical, geochemical and mineralogical. The physical analysis has been done in the laboratory of faculty of agronomy and agricultural sciences of university of Dschang. It consisted in determining the specific weight of each type of facies from the hydrostatic balance.

The microscopic analysis made it possible to observe in thin sheet the samples of undisturbed bauxite which 
were cut, indurated, polished and stuck with resin in the faculty of sciences of the University of Dschang.

X-ray diffractometry (XRD) and thermal analysis (TDA/TGA) have been done in the faculty of sciences of university of Hiroshima and were used for the mineralogical analysis. TGA/TDA coupled thermal analyses were used to evaluate the losses of molecular water contained in the hydroxides and silicates of alumina from the ground samples, sieved on the powders having a size of less than $2 \mathrm{~mm}$. The minerals were identified according to a temperature range and the method proposed by Njopwouo (1984). Radiation diffraction is a method which applies in particular to particles smaller than $2 \mu \mathrm{m}$ (clay).

The geochemical analysis was done by X-ray fluorescence in the university of Hiroshima for the determination and quantification of major elements by ICP-AE spectrometry on ground and sieved samples $(<2 \mathrm{~mm}) .100 \mathrm{mg}$ of powder were melted with $300 \mathrm{mg}$ of lithium Meta - Borate $\left(\mathrm{LiBO}_{2}\right)$ for 1 hour at $980{ }^{\circ} \mathrm{C}$ dissolved in $1.55 \mathrm{M}$ nitric acid.

\section{Results}

\subsection{Geomorphology and Distribution of Bauxites in the Locality of Bangam}

The soil cover of our study area consists mainly of continuous and discontinuous laterite bauxites. They are also found at the top of the plateaus and on the hillsides in the locality of Bamendjou, Fotouni and Batié which can be described here as prospects. Geomorphology is typical of the relief of West Cameroon, Hills slightly to strongly inclined, convex-concave with U-shaped valleys and flat bottom in places. This landscape presents undulations with residual mounds. Here we distinguish three great levels of bauxitization such as: the upper level between $1780-1620 \mathrm{~m}$, which are constituted by aboriginal bauxites and continuous at the top of plateaus, the intermediate level between $1620-1540 \mathrm{~m}$, this level consists of the bauxites reworked at the top of the hills and on the flanks, between $1540-1400 \mathrm{~m}$ at this level of the talwegs, one meets crushed duricrust gravels and some boulders. These duricrust on the whole occupy an area of about $9.2 \mathrm{~km}^{2}$ (see figure.2) organized as follows.

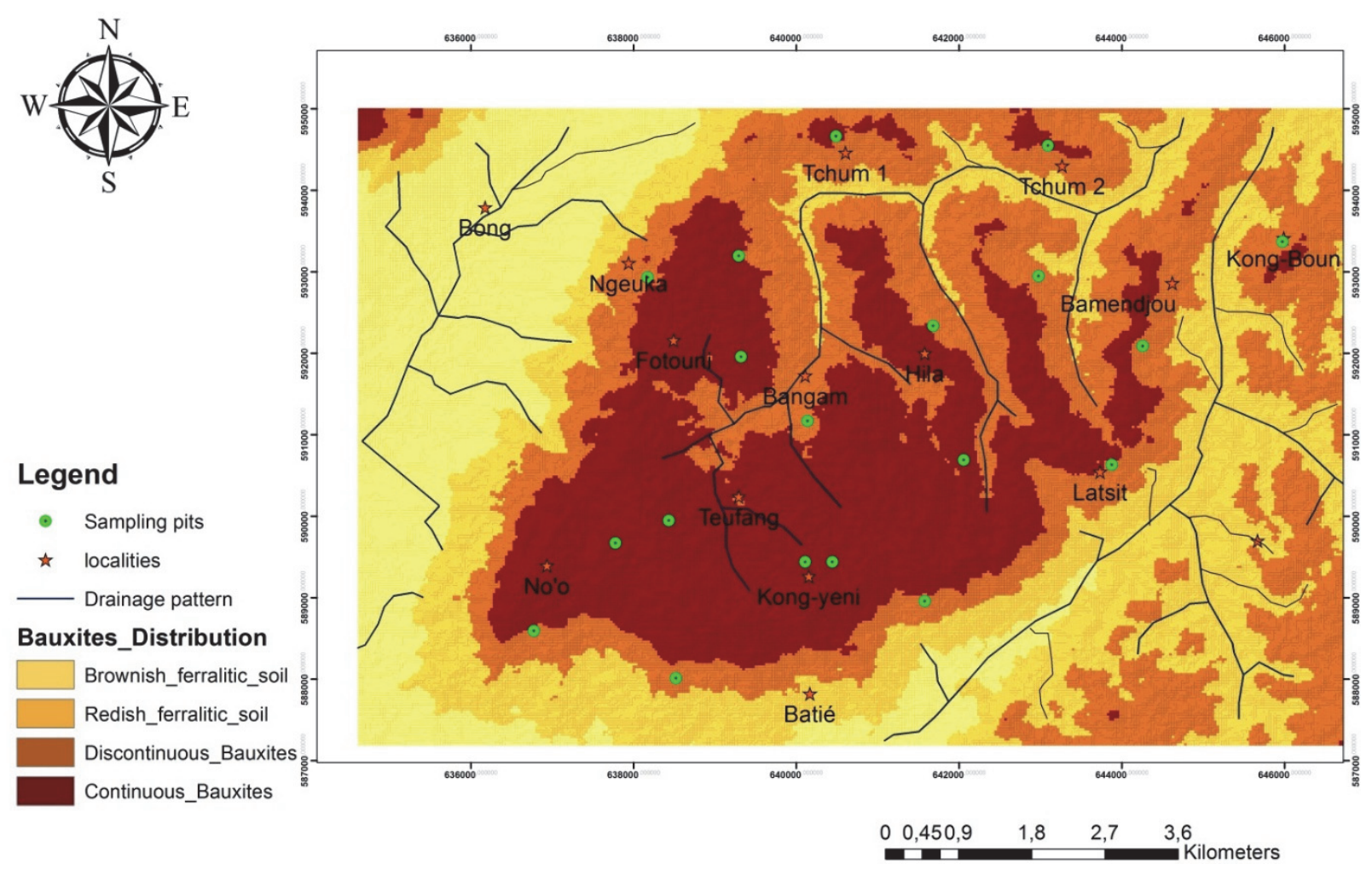

Figure 2. The distribution of Bangam bauxite deposits in the western Cameroon

\subsubsection{The Bauxite Duricrust of the Plateaus}

We can distinguish in the study area the Tchum plateau in Bamendjou, the Sojien plateau and the Kong-Top plateau in Fotouni, which have $1 \mathrm{~km}, 1.2 \mathrm{~km}, 0.9 \mathrm{~km}$ and $0.75 \mathrm{~km}$, respectively, in the form of an isolated pocket.

In Bangam, we have the Kong-yeni plateau which stretches as far as Batié about $1.5 \mathrm{~km}$ in the form of continuous 
slab. The weathered profile reveal a heterogeneity of compact facies (nodular, pisolitic and massive) of $13.2 \mathrm{~m}$, with colour variations from yellowish grey to base and brown red to surface through purplish red at intermediate level profile (see figure.3.1).

\subsubsection{The Bauxites Duricrust of the Hillsides}

It's notable that, they are some heterogeneity of duricrust such as the pisolitic, vacuolar, pseudobréccia and nodular facies. The bauxites are represented here in metric and decimetric blocks and balls, partially covered in some places by ferralitic soil. The observation of the alteration profiles (see figure.3.2) here shows a variation in the size of the blocks decreasing from the bedrock to the surface of the profile. The thickness of the duricrust is about $6 \mathrm{~m}$. The blocks are separated by reddish and brownish clays.

\subsubsection{The Gravelous Duricrust of the Talwegs}

They are found much more at the footslope of hills and plateaux, made up of a mixture of particles of centimetric size and rarely decimetric. The alteration coat (see figure.3.3) here shows a pedological succession much richer reddish clay, mottled brownish and yellowish grey and the duricrust are non-existent.

\subsection{Overview of Alteration Profiles}

Manual digging of the wells were done in a topographic sequence and shows a lateral and vertical variation along the profile. In general, the thickness of the bauxites is $13.20 \mathrm{~m}$ on the plates, very strongly consolidated and without discontinuity notorious along the profile (see figure 3.1), unlike the summits and sides of hills where the duricrust have a thickness of between $6 \mathrm{~m}$ with discontinuities along the profile (see figure. 3.2). The lithological sequence indicates that the alteration mantle is developed in situ and the profiles present everywhere the same organization, except in the talwegs where the profiles (see figure.3.3) are truncated or without duricrust. To summarize, the following organization can be observed:

- $\quad 0$ - $30 \mathrm{~cm}$ : there is here a weak layer of black soil (7.5G.2/1.5); a sharp boundary consisting mainly of organic soil and fragment of partially decomposed plants.

- $\quad 30-300 \mathrm{~cm}$ : this organic-mineral horizon is mostly composed of a mixture of reddish clay (10R.3/3). The nodules are strongly present with a grains size from $\mathrm{mm}$ to $\mathrm{cm}$; the boundary with the horizon is gradual.

- $\quad 300-1300 \mathrm{~cm}$ : the mean thickness of bauxites is around $960 \mathrm{~cm}$ and highly indurated. The blocks are strongly consolidated on top the plateau and hills (see figure.3.1). The boulders are bonded to each other by particles of clay that control an intense leaching process on the plateau and hills (see figure.3.2). The nodular, massive, pisolitic facies are strongly represented along the profile and their size decreases considerably from top to base. The colour also varies according to the facies, not to mention the islands of clays that line the pisoliths. The transition is gradual with the underlying horizon by the size of the blocks.

- $1300-1500 \mathrm{~cm}$ : also known as fine saprolite, characterized by strong humidity and greyish clay dominance (7.5YR.6 / 4), whitish (10YR.5 / 2) and reddish (10R.3 / 3).

- $\quad 1500-1800 \mathrm{~cm}$ : here the degree of humidity is also very pronounced with a dominance of a coarse saprolite; the clay texture is whitish yellow (10YR.7.5 / 11) and greyish (7.5GY.4, 5/2). The relics of the greyish bedrock are clearly observed and the mafic features remind us of basalts.

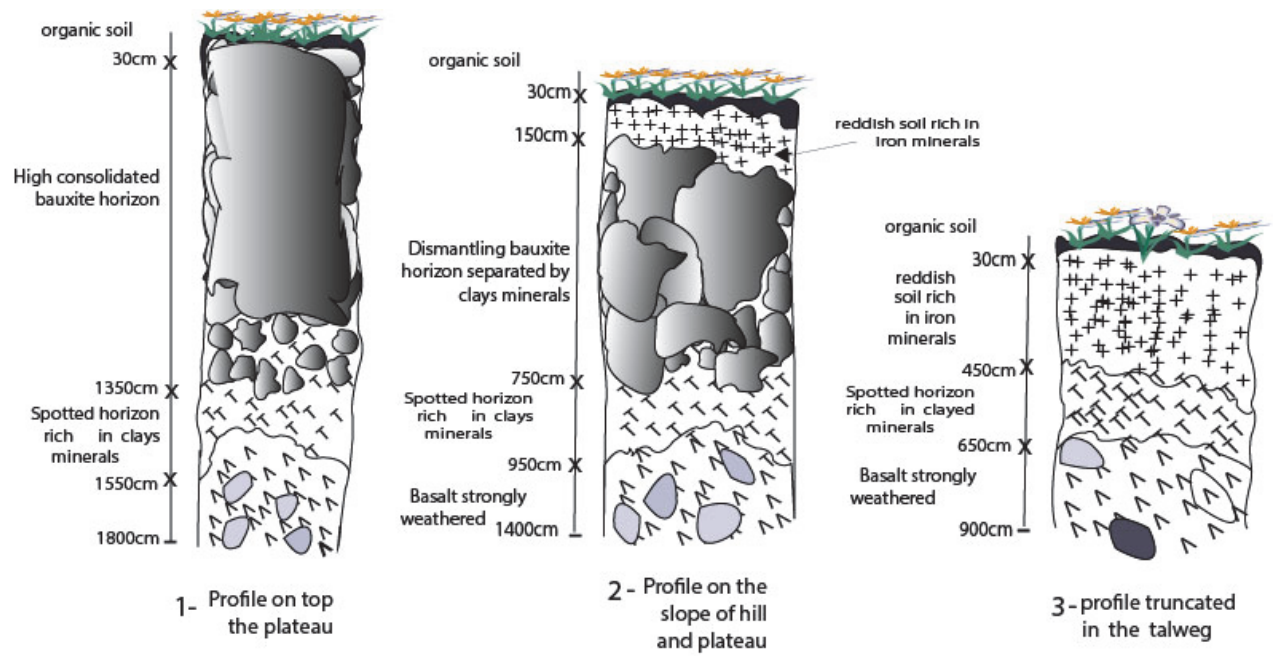

Figure 3. Lithological sequences of profile in Bangam site 


\subsection{The Facies Encountered}

\subsubsection{The Massive Facies}

These are the most abundant facies, much more observable at the top of plateaus. They are very compact, purplish red, very low porosity and sometimes almost non-existent with a bulk density of $2.8 \mathrm{~g} / \mathrm{cm}^{3}$.

\subsubsection{The Pisolitic Facies}

They are found on the flanks and summits of the hills, reddish purplish and rich in hematite and some relics of goethite. They are sometimes associated (coexist) with massive facies, with a bulk density of $2.4 \mathrm{~g} / \mathrm{cm}^{3}$. The pisoliths are less than $1 \mathrm{~cm}$ in size and sometimes enclosed by patches of reddish-yellow clays.

\subsubsection{The Nodular Facies}

This type is characterized by a richness of nodule of black colour and in coalescence with a clay matrix of purplish red colour. The nodules have sizes less than $1 \mathrm{~cm}$ and overall the bulk density is $2.3 \mathrm{~g} / \mathrm{cm}^{3}$.

\subsubsection{The Pseudobréccia Facies}

Very weakly represented and with a bulk density of $2.6 \mathrm{~g} / \mathrm{cm}^{3}$, they consist essentially of a yellowish matrix and a cryptocrystalline mixture of materials strongly indurated by the detrital particles.

\subsubsection{The Vacuolar Facies}

The vacuolar facies are pinkish white to brownish white, poorly represented in the locality of Bangam. They are essentially characterized by high porosity and a vesicular (vuggy) texture, very hard to friable. The sizes of vacuoles are approximatively between $2 \mathrm{~cm}$ to $3 \mathrm{~cm}$. very light in weight with $1.9 \mathrm{~g} / \mathrm{cm}^{3}$ of bulk density.

\subsection{Petrography of Bauxites in Bangam Locality}

The petrographic study of Bangam bauxites shows in thin section the presence of secondary minerals such as gibbsite, kaolinite, goethite and hematite, which are presented here in the form of cutanes and clayed texture. Magnetite is also present as opaque oxides in a yellowish red matrix with no pleochroism.

\subsubsection{Hematite /Goethite}

Hematite and goethite are represented in thin section below (see figure 4) by the reddish and brownish red zone. They are characterized by a low pleochroism and two forms orientation of a structure, massepic in some sections and insepic in anothers. They are always found in association between the fissures of primary minerals and which sometimes serve as ferruginous bridge between gibbsite and kaolinite. Hematite and goethite are mostly represented in pisolitic and pseudobreccia facies. Hematite is mostly associated with goethite and appears commonly between primary minerals.

\subsubsection{Magnetite}

Magnetite appears in thin section by an irregular shape, very darkness colour and no pleochroism (see figure 4B). It's mostly associated with others iron minerals and in inclusion with the remains of primary mineral.

\subsubsection{Gibbsite}

The gibbsite mineral is always colourless in thin section and there isn't colour of iron mineral (Delvigne.1970) and whitish in some section (Biton.1988). It presents as cutanes and appear without orientation (insepic). Gibbsite is mainly found in the transmineral crack and takes place gradually to the detriment of iron oxides (see figure 4B and 4C).

\subsubsection{Kaolinite}

This alumina mineral (see figure.4B) are strongly observed in a thin section of grey-bluish to whitish colour which progressively takes place of some unidentified primary minerals. It is observed here and the grey transition zone of kaolinite which marks the transition from kaolinite to gibbsite. 

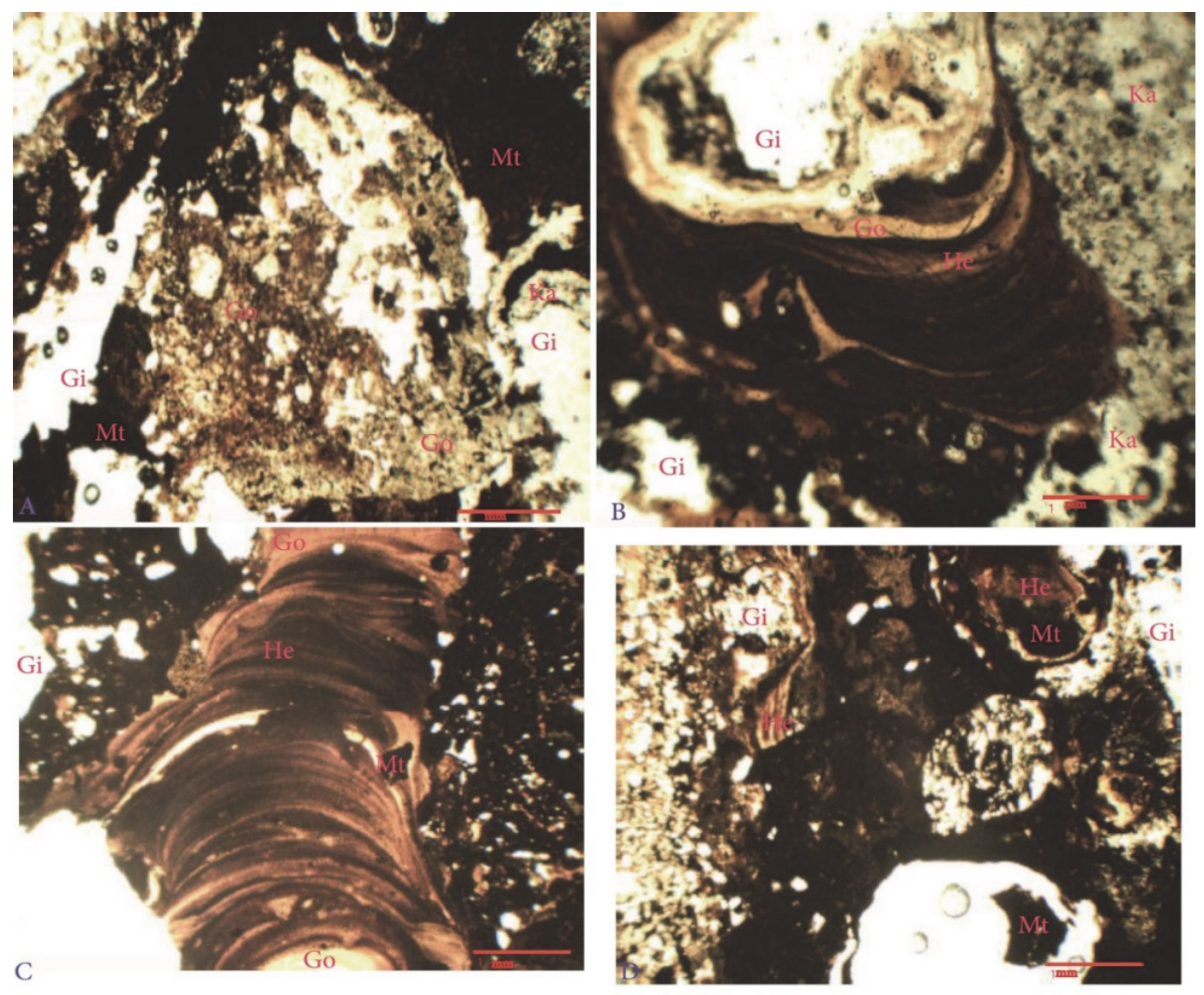

Figures 4. Microscopic observation of bauxite in thin section

$\mathbf{G i}=$ gibbsite. $\mathbf{H e}=$ hematite. $\mathbf{G o}=$ goethite. $\mathbf{K a}=$ kaolinite. $\mathbf{M t}=$ magnetite

\subsection{Mineralogy of Bauxites in the Bangam Locality}

The mineralogical analyses have been carried out by DRX and thermal (TDA/TGA) methods 4.5.1 The results by DRX method.

The results of mineralogical analyses are shown in figure 5. Two types of paragenesis are observed here, the first consisting of minerals such as gibbsite with its characteristic peaks at $4.83 \mathrm{~A}^{\circ}, 4.36 \mathrm{~A}^{\circ}, 3.34 \mathrm{~A}^{\circ}, 3.09 \mathrm{~A}^{\circ}$, Goethite with its peaks at $4.15 \mathrm{~A}^{\circ}, 2.83 \mathrm{~A}^{\circ}$, magnetite at $1.49 \mathrm{~A}^{\circ}$, ilmenite at $3.72 \mathrm{~A}^{\circ}$ and hematite at $3.67 \mathrm{~A}^{\circ}$. The second paragenesis consists of kaolinite with its peaks at $7.15 \mathrm{~A}^{\circ}, 4.43 \mathrm{~A}^{\circ}, 4.25 \mathrm{~A}^{\circ}$ and other previously mentioned minerals. We notice that in the table 1 below, gibbsite and kaolinite are the most abundant minerals with a $30.65 \%-75 \%$ and $11 \%-32.23 \%$ contents respectively, hematite $(3.7 \%-10.9 \%)$, goethite $(4.42 \%-13.2 \%)$, magnetite $(1.1 \%-3.53 \%)$ and ilmenite $(2.54 \%-4.81 \%)$ are the different iron minerals present in these bauxites. The titanium mineral is represented by anatase with contents between $0.99 \%-4.44 \%$.

Table 1. Minerals and their relative abundance in various facies

\begin{tabular}{llllll}
\hline Facies & Massive & Pisolitic & Pseudobreccia & Nodular & Vaccuolar \\
\hline Gibbsite (\%) & 75 & 37.1 & 60.43 & 30.65 & 58.18 \\
Kaolinite (\%) & 12.5 & 31 & 11 & 32.23 & 24.47 \\
Ilmenite (\%) & - & 4.81 & 2.87 & 2.54 & - \\
Hematite (\%) & 5.52 & 10.9 & 7.2 & 10.3 & 3.7 \\
Goethite (\%) & 4.42 & 13.2 & 9.53 & 9.93 & 10 \\
Magnetite (\%) & 1.1 & 1.42 & 2.54 & 2.96 & 3.53 \\
Anatase (\%) & 0.99 & - & 4.44 & 1.5 & - \\
\hline
\end{tabular}




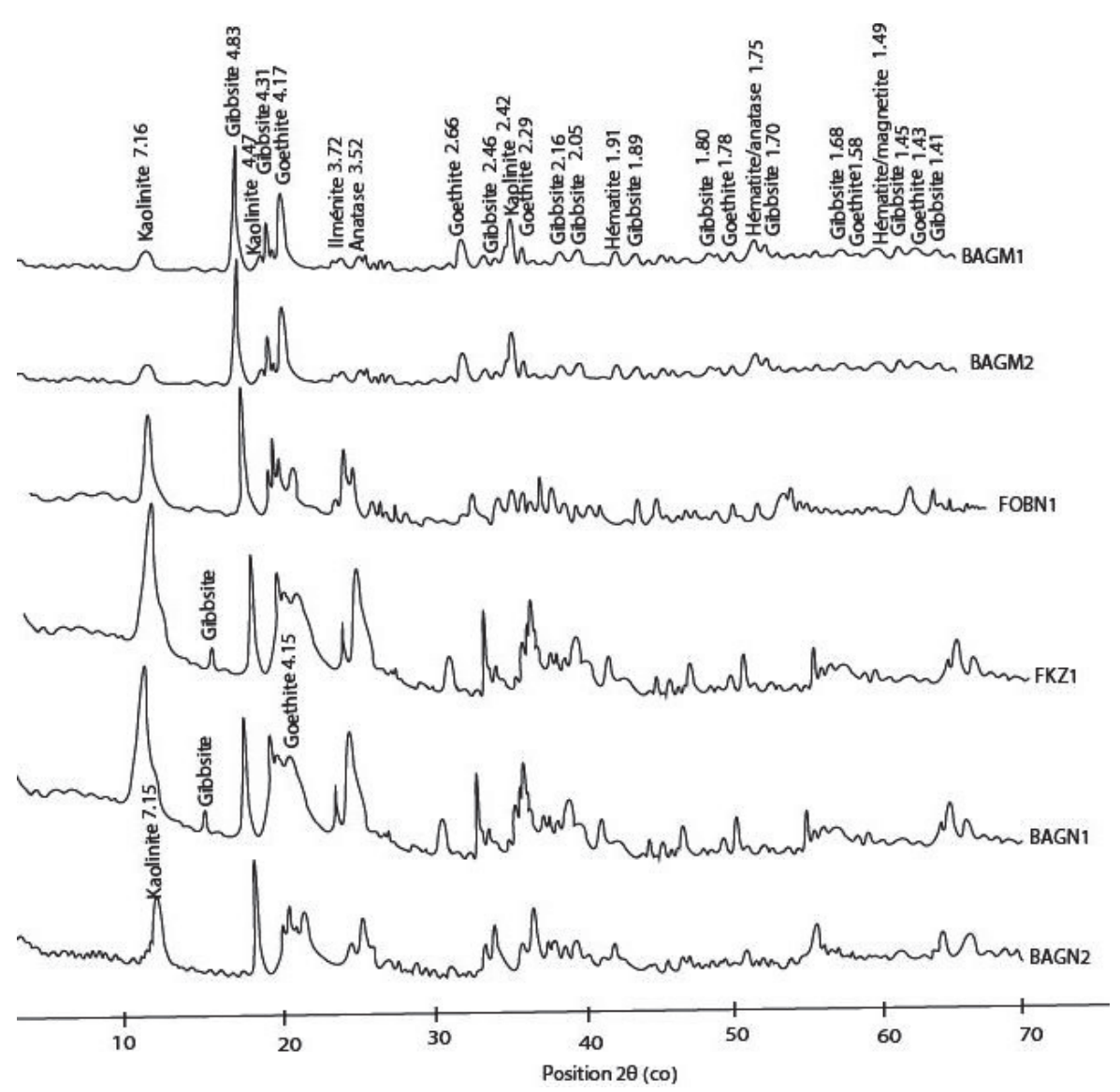

Figure 5. X-ray diffractograms of some facies

\subsubsection{The results by TDA/TGA Methods}

The thermal differential analysis (figure.6a) confirms the presence in bauxites some hydroxides (gibbsite, goethite ...) and alumina silicates (kaolinite) as indicated by the endothermic peaks between $200^{\circ} \mathrm{C}-400^{\circ} \mathrm{C}$ and between $400^{\circ} \mathrm{C}-600^{\circ} \mathrm{C}$ (see figure 6a) respectively. The exothermic peaks at $968^{\circ} \mathrm{C}$ simply indicate a reorganization of the metakaolinite for spinel formation (figure 6b). However, we observe the inflexion of thermal gravimetric analysis curve between $200^{\circ} \mathrm{C}-400^{\circ} \mathrm{C}$ and $400^{\circ} \mathrm{C}-600^{\circ} \mathrm{C}$ which indicates the losses of weight of hydroxides (gibbsite, goethite...) and kaolinite respectively (see figure 6b).

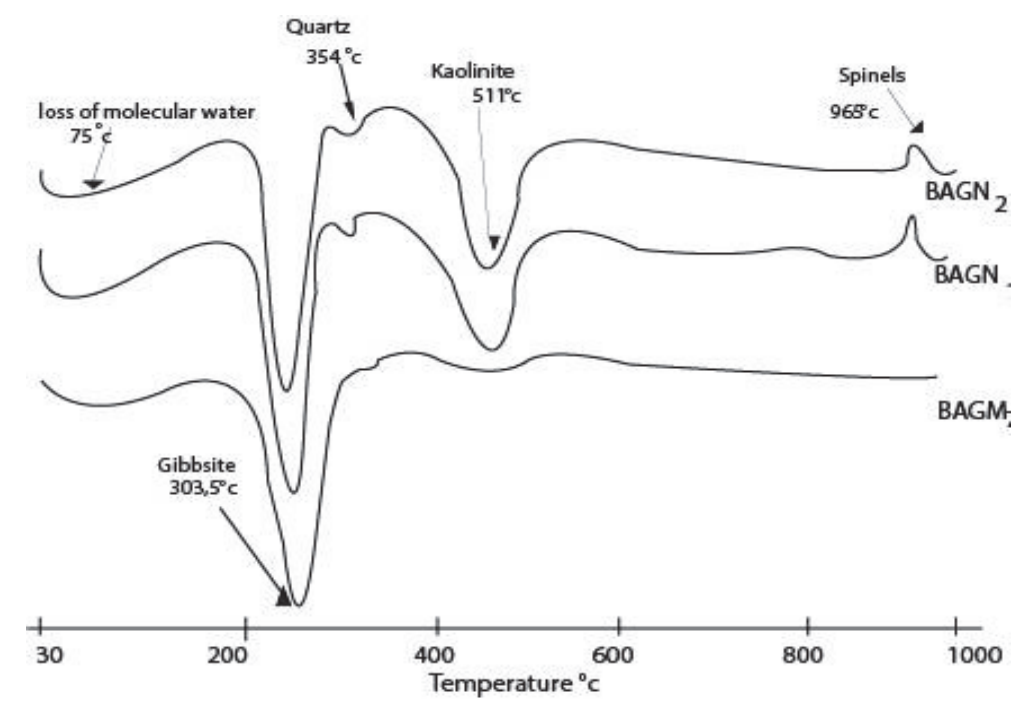




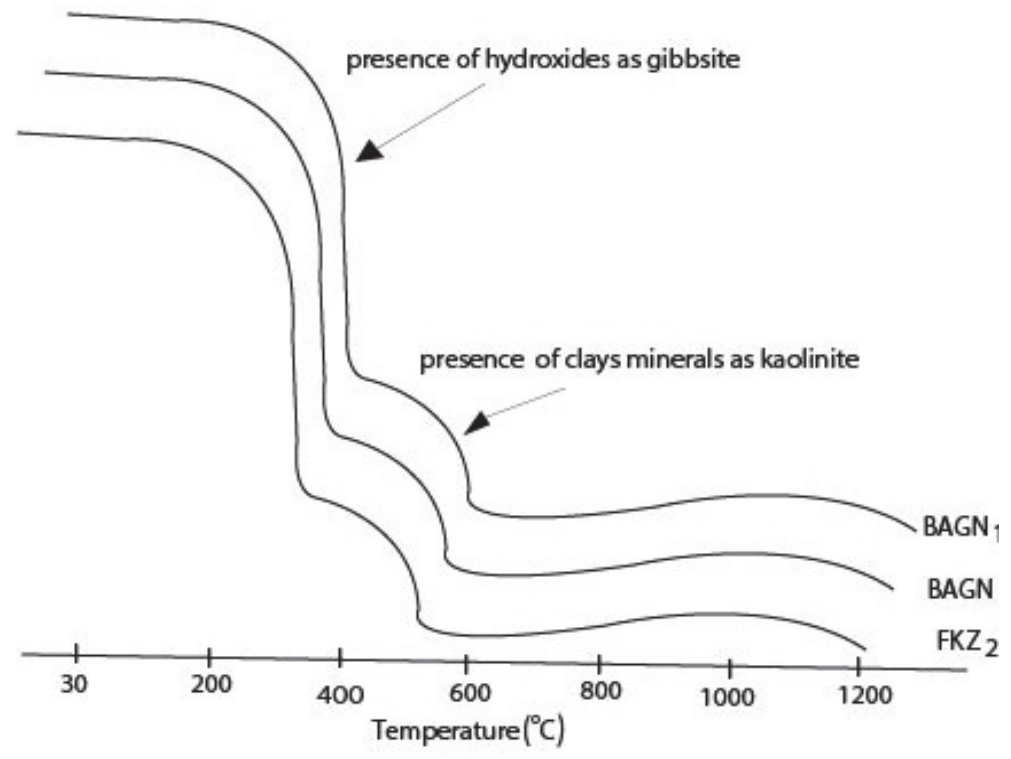

Figure 6. Curves of thermodifferential (a) and thermogravimetric (b) analysis of some facies

\subsection{Geochemistry of Bauxite Facies}

These analyses were carried out by X-ray fluorescence (XRF) and are reported in Table 2. The contents of the major elements, $\mathrm{Al}_{2} \mathrm{O}_{3}, \mathrm{Fe}_{2} \mathrm{O}_{3}, \mathrm{SiO}_{2}$ are predominantly represented by other oxides such as $\mathrm{TiO}_{2}, \mathrm{P}_{2} \mathrm{O}_{5}, \mathrm{MgO}$, $\mathrm{MnO}, \mathrm{CaO}, \mathrm{K}_{2} \mathrm{O}$ are weakly represented and $\mathrm{Na}_{2} \mathrm{O}$ is completely evacuated in the various facies. The table 2 below show that, the massive, vacuolar, pisolitic and pseudobreccia have a high content of alumina and a low content of silica and iron, however, the nodular facies has $\mathrm{Al}_{2} \mathrm{O}_{3}, \mathrm{Fe}_{2} \mathrm{O}_{3}$ and $\mathrm{SiO}_{2}$ of $39.88 \%, 26.8 \%$ and $15.41 \%$ respectively. The Chemical Index of Alteration (CIA) is very high (0.99) and Index of Ruxton is very low and less than 1(0.05-0.1) in difference facies.

Table 2. Geochemistry of different facies

\begin{tabular}{|c|c|c|c|c|c|c|c|c|c|c|c|c|c|c|}
\hline Facies & $\mathrm{SiO}_{2}$ & $\mathrm{Al}_{2} \mathrm{O}_{3}$ & $\mathrm{Fe}_{2} \mathrm{O}_{3}$ & $\mathbf{K}_{2} \mathbf{O}$ & $\mathrm{TiO}_{2}$ & $\mathrm{Na}_{2} \mathrm{O}$ & $\mathrm{CaO}$ & MgO & $\mathrm{P}_{2} \mathrm{O}_{5}$ & MnO & Loi & Total & CIA & RI \\
\hline \multirow[t]{3}{*}{ Massive } & 3.00 & 59.69 & 9.41 & 0.01 & 1.91 & 0 & 0.03 & 0.12 & 0.34 & 0.03 & 25.8 & 100.98 & 0.99 & 0.05 \\
\hline & 2.61 & 60.41 & 9.31 & 0.01 & 1.93 & 0 & 0.03 & 0.12 & 0.34 & 0.03 & 25.8 & 100.36 & 0.99 & 0.04 \\
\hline & 2.59 & 60.25 & 9.12 & 0.01 & 1.99 & 0 & 0.03 & 0.12 & 0.34 & 0.03 & 25.8 & 99.98 & 0.99 & 0.04 \\
\hline \multirow[t]{3}{*}{ Nodular } & 22.42 & 38.60 & 17.95 & 0.02 & 3.24 & 0 & 0.04 & 0.10 & 0.16 & 0.03 & 16.84 & 100.03 & 0.99 & 0.58 \\
\hline & 21.51 & 38.29 & 18.71 & 0.02 & 3.31 & 0 & 0.03 & 0.09 & 0.17 & 0.03 & 16.84 & 99.03 & 0.99 & 0.56 \\
\hline & 2.31 & 42.77 & 42.31 & 0.01 & 3.04 & 0 & 0.03 & 0.08 & 0.42 & 0.05 & 10.30 & 101.32 & 0.99 & 0.05 \\
\hline \multirow[t]{2}{*}{ Pseudobreccia } & 4.81 & 47.14 & 13.27 & 0.01 & 2.93 & 0 & 0.02 & 0.19 & 0.50 & 0.07 & 30.95 & 98.95 & 0.99 & 0.1 \\
\hline & 4.75 & 51.14 & 14.38 & 0.01 & 3.19 & 0 & 0.02 & 0.16 & 0.48 & 0.06 & 26.02 & 100.24 & 0.99 & 0.09 \\
\hline \multirow[t]{3}{*}{ Pisolitic } & 2.35 & 46.81 & 24.10 & 0.01 & 3.94 & 0 & 0.02 & 0.11 & 0.12 & 0.04 & 20.57 & 101.32 & 0.99 & 0.05 \\
\hline & 2.69 & 39.95 & 42.54 & 0.01 & 4.13 & 0 & 0.03 & 0.13 & 0.55 & 0.05 & 10.30 & 97.61 & 0.99 & 0.06 \\
\hline & 6.22 & 43.48 & 13.31 & 0.01 & 3.97 & 0 & 0.03 & 0.11 & 0.24 & 0.04 & 20.20 & 100.07 & 0.99 & 0.14 \\
\hline \multirow[t]{2}{*}{ Vacuolar } & 12.00 & 47.33 & 17.35 & 0.03 & 3.25 & 0 & 0.05 & 0.22 & 0.25 & 0.04 & 20.41 & 101.33 & 0.99 & 0.25 \\
\hline & 15.05 & 48.39 & 16.45 & 0.03 & 2.82 & 0 & 0.07 & 0.23 & 0.26 & 0.04 & 16.70 & 100.04 & 0.99 & 0.31 \\
\hline
\end{tabular}

\section{Interpretation and Discussion of Results}

\subsection{Relationship Between Bauxite and Geomorphology}

Several studies have been carried out in Africa and Cameroon on the vertical organization and evolution of bauxite duricrust in the landscape, these bauxites have been develop on very thick mantle of alteration which forms old residual surfaces Valeton (1972 \& 1981). The bauxites of Bangam are arranged in three levels, namely, the upper level, the intermediate level and the lower level qualify as bowés by Morrin (1980) and Momo et al. (2011). Their position at the top of the hills and plateaus are developed describes as an African surface, Boulangé (1984) show the similarity in Ivory Coast and in Ghana. According to Boulet et al (1977), Bocquier (1971) their relation with 
geomorphology just classified them in two groups known as: authiginous bauxite formed in situ on top the plateau and hills and allogenous bauxite in the talwegs and interfluve favour by the dismantling of continuous bauxites on top the plateau and hills. The Morphology of the relief of western Cameroon which the bauxites of Bangam belong is the seat of several tectonics phenomena responsible for this geomorphology. Morin (1980) and Nkouathio et al. (2008) explain this morphology by the sets of the tectonic along the Cameroon line at the end of the Miocene, which created faults on both sides of the locality. The degradation of bauxites is favoured by the tropical humid climate and by the set of this brittle tectonic influencing considerably the shape of the bauxites (Leprun, 1977; Morin, 1980). For King (1967), the African morphologies depend on the progressive erosion and peneplanation which are favoured by the hydrographic network which generally get along with the faults (Nono et al., 2001) and are responsible for the reduction and variations of the thickness of the duricrust $13.2 \mathrm{~m}$ above the plateaus, 6 to $5 \mathrm{~m}$ on the flanks of hills and plateaus, (Temgoua et al., 2002; Bitom et al., 2003). According to Hieronymus, (1972), the bauxitic surfaces of Bangam have been cut by the hydrographic network, which has left glaciers and ridge lines, separated by numerous valleys.

The analysis of the landscape and the pedological coverage of the study area reveal the following facts: the hills are very narrow with very steep slopes, unlike the plateaus where the slopes are slightly inclined. The presence of the gibbsitic-dominated breastplates (Bitom et al., 2004), which has contributed to the development of a thick soil-cover (Eno Belinga, 1984; Bitom, 1988; Kamgang Beyala, 1998) at the level of the hills, a compact pedologic horizon at the top of the plateaus and in the whole of a spotted horizon reflect the climatic imbalance (contrast) of the locality (Boulet et al., 1984). It seems that the dismantling of Bangam's bauxites is not limited to the tropical climates with contrasting seasons. In effect, the works of Likiby et al. (2010) at Djoulgouf (far north Cameroon) show that the dismantling of duricrust can be caused by the thermoclastic or mechanic destruction and geochemical process of hematite and goethite replacement. This phenomenon can be transposed in Bangam which is under the influence of the same climatic condition. The dismantling of the duricrust is much more linked to geochemical casting or a hematite goethization, according to Tardy and Nahon (1985), these two minerals played an important role in the process of cuirassing.

\subsection{Mineralogy and Geochemistry of Bauxite in Bangam Locality}

The bauxite deposits in Bangam are different in mineralogy and geochemistry according to the types of facies. Five types of facies were identified and described according to the nomenclature proposed by Tardy (1993), the most abundant and dominant types are massive facies, follows by the pisolitic facies. Graham et al (2012), the majority of bauxites in the world are pisolitic and massive bauxites. The five types of facies which are present have a bulk density between $1.9 \mathrm{~g} / \mathrm{cm}^{3}$ and $2.8 \mathrm{~g} / \mathrm{cm}^{3}$; it simply means that, these different facies have lost a chemical element during the ferralitization process (D'Hoore, 1954 in Boulangé, 1984). According to Tardy (1993), pisolitic and nodular facies are evolved forms of massive facies during leaching. Vacuolar facies are formed by the destruction of the gulb (glebular) bridges contained in the massive facies. The nodular facies with a high silica and kaolinite contents might be the resilicification of bauxite during the leaching process following by the equation proposed by Bitom (1988): $2 \mathrm{Al}(\mathrm{OH})_{3}+2 \mathrm{SiO}_{2} \longleftrightarrow \mathrm{Al}_{2} \mathrm{Si}_{2}(\mathrm{OH})_{4} \mathrm{O}_{5}+\mathrm{H}_{2} \mathrm{O}$ or the solubility of the silica is generally controlled by alumina which the both combines to form alumino silicates such as kaolinite, Okamoto $e t$ al., (1957). According to Annan and Butt (2010), the pseudobréccia facies is the richest in gibbsite and low contents of iron and silicate and might be qualify as good bauxite quality in Cameroon.

The $\mathrm{SiO}_{2} / \mathrm{Al}_{2} \mathrm{O}_{3}$ ratio once more called Ruxton index (1968) is much lower than 1 on each facies, indicating the presence of gibbsite (Beauvais, 1991) and the Chemical Index of Alteration (CIA) of Nesbitt and Young (1982) values derived from major element composition show an extremely high values (0.99), is an evidence that Bangam bauxite derive of complete alteration of clay phase. Gibbsite is the most abundant mineral of Bangam bauxites and formed during the ultimate stage of alteration (Tetsuhiro et al., 2010) known as allitisation, follows by kaolinite known as monosialitisation, hematite, goethite, ilmenite, magnetite and anastase. The gibbsite is observed in thin section a whitish zone qualified by Bitom (1988) as starting zone of alteration of primary minerals during a pseudomorphosis process. Gibbsite is only formed in an acid medium, to the detriment of boehmite which forms only in basic medium with high $\mathrm{CaO}$ contents, Smith (1986). For Bardossy (1989), the bauxites dominated by gibbsite are much more associated with goethite sometimes with hematite and kaolinite Boeglin (1990).

The presence of hematite and goethite in antagonistic proportions is due to competition in ferralitic medium, also called ferrolysis between these two minerals observed by Cornell and Schwertman (1996), Cornell et al (1990). Think of a dehydration of goethite for the formation of hematite.

The frequency of chemical elements (see figure.7) in Bangam's bauxite is $48.01 \%$ of $\mathrm{Al}_{2} \mathrm{O}_{3}, 7.82 \%$ of $\mathrm{SiO}_{2}, 19.09 \%$ of $\mathrm{Fe}_{2} \mathrm{O}_{3}, 3.05 \%$ of $\mathrm{TiO}_{2}, 0.03 \%$ of $\mathrm{CaO}, 0.01 \% \mathrm{~K}_{2} \mathrm{O}, 0.13 \% \mathrm{MgO}, 0.04 \% \mathrm{MnO}, 0.00 \% \mathrm{Na}_{2} \mathrm{O}$ and $0.32 \% \mathrm{P}_{2} \mathrm{O}_{5}$ 
which corresponds to the term loaned by Berthier in 1801 to leases in France when this mineral was discovered for the first time. In addition, the $\mathrm{SiO}_{2}-\mathrm{Fe}_{2} \mathrm{O}_{3}-\mathrm{Al}_{2} \mathrm{O}_{3}$ triangular diagram below (see figure.8) also show us that, the sample collected (massive facies, pseudobreccia facies and vacuolar facies) are converged toward the alumina side, but it's notable that some facies (pisolitic and nodular) have a high contents of iron and silicate. In spite of, the bauxites with the high contents of iron and silicate can be used in the industry of manufactured cement, Eno Belinga (1971). If we do a comparative study with the Ghanaian bauxites (Monade \& Gawu 2009), and Cameroonian bauxites (see table 3), for Bardossy (1989), Eno Belinga (1971), they are real reservoirs of sesquioxides of alumina and iron useful in industries. The bauxites of Bangam show that they are still rich in iron and alumina, the high contents of iron oxyhydroxides and alumina in some facies indicate just the formation of these minerals from a basaltic parent rock and especially during the phenomenon of relative accumulation (Annand \& Butt, 2010; Mc Queen \& Scott 2008). Valeton (1972 \& 1981) describes it as protobauxites that have been set up under a process of allitization and monosiallitization due to an abundance of rain (1712.10mm) or because of the hydrographic network, the steep inclined slopes which favoured the leaching of the environment, Momo et al. (2011), Aristizabal et al. (2005).

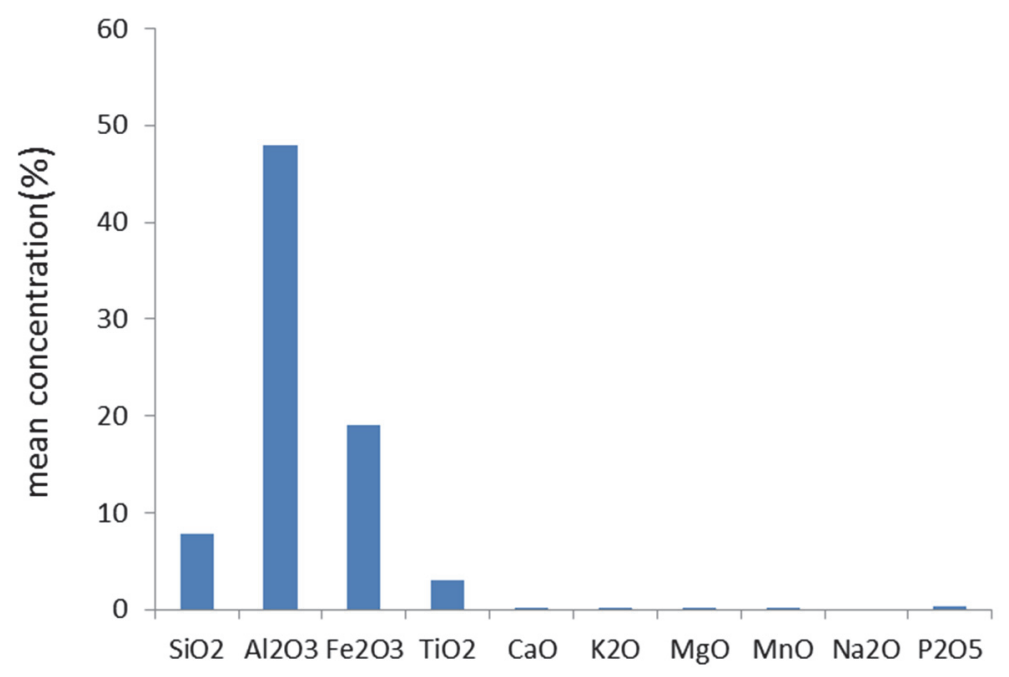

Figure 7. Histogram of mean values of different oxides

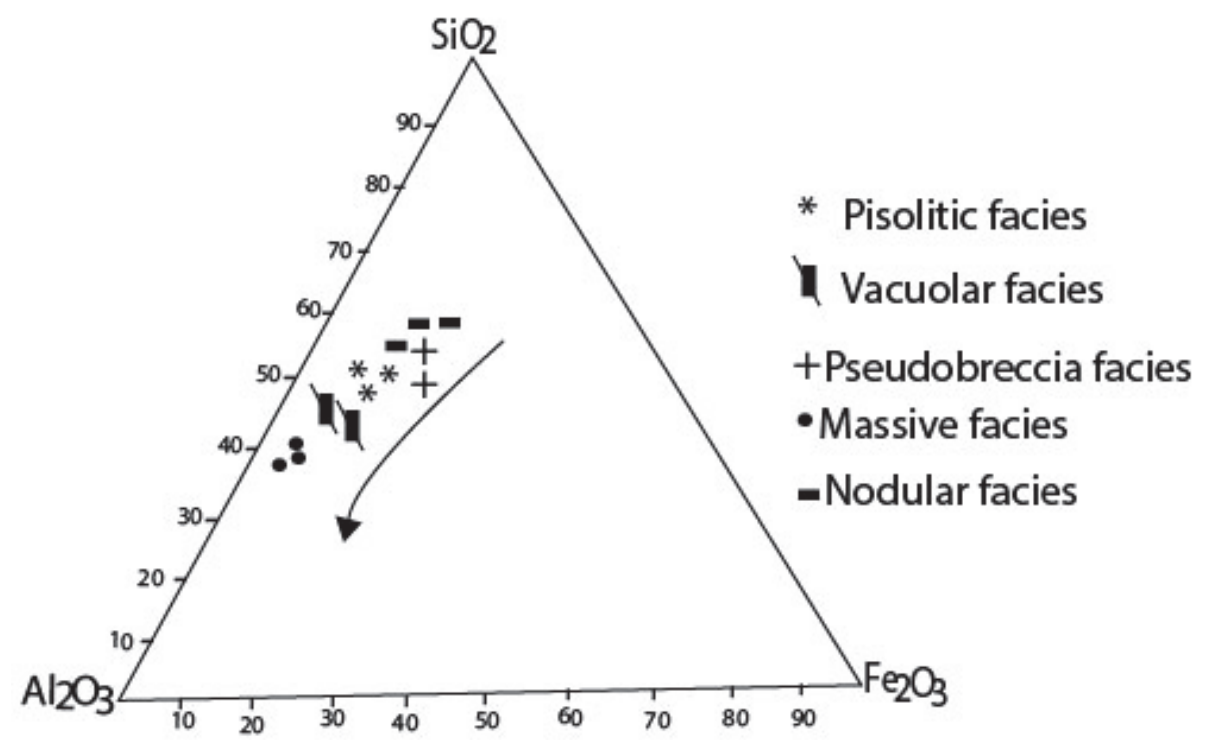

Figure 8. Triangular diagram $\mathrm{SiO}_{2}-\mathrm{Al}_{2} \mathrm{O}_{3}-\mathrm{Fe}_{2} \mathrm{O}_{3} \ldots$ 
Table 3. Geochemical comparison between the Bangam bauxite, Doumbouo-Fokoue-, Briskok in Adamaoua region and Awaso (Ghana)

\begin{tabular}{|c|c|c|c|c|c|c|c|}
\hline Country & Locality & Sample ID & $\mathrm{Al}_{2} \mathrm{O}_{3}$ & $\mathrm{SiO}_{2}$ & $\mathrm{Fe}_{2} \mathrm{O}_{3}$ & Colour & Sample type \\
\hline \multirow[t]{5}{*}{ Cameroon } & \multirow[t]{5}{*}{ Bangam } & $\mathrm{BAGM}_{2}$ & 60.41 & 3.00 & 9.41 & Brownish & Boulder \\
\hline & & BAGM $_{1}$ & 60.25 & 2.61 & 9.12 & Greyish & Boulder \\
\hline & & $\mathrm{BAGM}_{7}$ & 42.77 & 2.31 & 42.31 & Reddish & Boulder \\
\hline & & $\mathrm{BAGN}_{1}$ & 38.29 & 21.5 & 18.71 & Grey-red & Float \\
\hline & & $\mathrm{FKZ}_{1}$ & 47.14 & 4.81 & 13.27 & yellowish & Float \\
\hline \multirow[t]{5}{*}{ Cameroon } & \multirow[t]{5}{*}{ Briskok } & 100512 & 57.5 & 0.64 & 5.90 & Grey-red & Float \\
\hline & & 100924 & 31.4 & 31.5 & 16.05 & Grey-red & Float \\
\hline & & 100986 & 60.1 & 0.99 & 3.04 & Grey-red & Float \\
\hline & & 100538 & 18.3 & 1.81 & 61.3 & Red & Float \\
\hline & & 100513 & 59.3 & 0.59 & 2.90 & Grey-red & Float \\
\hline \multirow[t]{2}{*}{ Cameroon } & \multirow[t]{2}{*}{ Doumbouo-Fokoue } & SA & 47.49 & 7.66 & 22.33 & Brown & Float \\
\hline & & $\mathrm{FO} 2$ & 49.49 & 1.81 & 20.24 & Whitish-grey & Float \\
\hline \multirow[t]{5}{*}{ Ghana } & \multirow[t]{5}{*}{ Awaso } & $\mathrm{A}_{1}$ & 45.90 & 27,00 & 1.22 & Yellowish & Outcrop \\
\hline & & $\mathrm{A}_{2}$ & 45.90 & 31.90 & 1.33 & Yellowish & Outcrop \\
\hline & & $\mathrm{A}_{5}$ & 44.02 & 37.60 & 0.37 & Whitish & Outcrop \\
\hline & & $\mathrm{BW}_{1}$ & 31.10 & 32.10 & 18.10 & Red-brown & Outcrop \\
\hline & & $\mathrm{BW}_{4}$ & 35.10 & 38.30 & 1.10 & Whitish & Outcrop \\
\hline
\end{tabular}

\section{Conclusion}

After studying the bauxites of Bangam, it is clear that they result from two phenomena of bauxitisation, namely ferralitisation (formation of massive facies, pisolitic, nodular and vacuolar facies) and cementation (formation of pseudobreccia facies) with a double setting between iron, aluminium and silica. The frequency of constitutive minerals shows a similarity with other Cameroonian bauxites (Doumbouo-Foukoue, Ngaoundal-Minim-Martap) and African bauxites (Ghana) with grades of gibbsite and kaolinite, which are the most sought-after minerals by mining companies.

According to the Tardy Classification (1993), they are protobauxites because they have formed under lateritic soil and a humid climate where gibbsite is the dominant mineral.

These bauxites have the characteristics of the former African bauxitic surfaces (African surface) formed since the Miocene under the effect of a process of bauxitisation with climatic contrast.

Allitization and monosiallitization are the two hydrological phenomena responsible for a thick alteration coat forming a bauxite duricrust of about $9.6 \mathrm{~m}$ on an area of about $9.5 \mathrm{~km}^{2}$. Their position at the top of the hills and plateeaus makes them real reservoirs of sesquioxides of iron and aluminium, which would make operation easier and less costly for an open-pit mine if ever a possible exploitation was considered.

\section{References}

Anand, R. R., \& But, C. R. M. (2010). A guide for mineral exploration trough the regolith on the Yilgarn craton, Werstern Australia. Australian Journal of Earth Science, 57(8), 1015-1114.

Aristizabal, E., Roser, B., \& Yokota, S. (2005). Tropical Chemical Weathering of Hillslope Deposits and Bedrock Source in the ABURRA Valley, Northern Colombian Andes. Engineering Geology, 81, 389-406

Bardossy, G., \& Aleva, G. J. J. (1990). Lateritic Bauxites, Developments in Economic Geology. Elsevier, Amsterdam, 27, 624.

Bardossy, G. (1989). Latertic bauxite deposits. A worldwide survey of observed fact.proc. of the 6th.Inter. cong. ICSOBA. Pocos.caldas, Brazil, travaux ICSOBA. Acad Yougoslave. Sci. Zagreb, 19(22), 11-18

Beauvais, A. (1991). Paléoclimats et dynamique d'un paysage cuirassé de Centrafrique.Morphologie, pétrologie et géochimie. Thèse Univ.de Poitiers, 297.

Bitom, D., Volkoff, B., \& Abossolo-Angue, M. (2003). Evolution and Alteration in Situ of Massive Iron Duricrusts in Central Africa. Journal of African Earth Sciences, 37, 89-101.

Bitom, D., Volkoff, B., Beauvais, A., Seyler, F., \& Ndjigui, P. D. (2004). Rôle des héritages latéritiques et du niveau des nappes dans l'évolution des modelés et des sols en zone intertropicale forestière humide. $C$. $R$. 
Geoscience, 336(2004), 1161-1170.

Biton, D. (1988). Organisation et évolution d'une couverture ferralitique en zone tropicale humide(Cameroun).Genèse et transformation d'ensemble ferrugineux indurés profonds. Thèse. Univ. Poitiers.164p.Multigr.

Bocquier, G. (1971). Genèse et évolution de deux toposéquences de sols tropicaux du Tchad. Interpétation biogéodynamique. Thèse Doct.Sc. Strasbourg et Mém O.R.S.T.O.M 1973. 62, 350p.

Boeglin, J. L. (1990). Evolution minéralogique et géochimique des cuirasses ferrugineuses de la région de Gaoua (Burkina Faso). Thèse Doct. Univ. Louis Pasteur, Strasbourg.187p.

Boulangé, B. (1984). Les formations bauxitiques et latéritiques de la Côte-d'Ivoire.Thèse de Doctorat d'Etat, Univ. Paris $V^{\text {ieme }} .354 \mathrm{p}$.

Boulet, R., Chauvel, A., \& Lucas, Y. (1984). Les systèmes de transformation en pédologie, Sci. du Sol, Cinquantenaire de l'AFES: 167-179.

Cornell, R. M., \& Schwertman, U. (1996). The iron oxides. Structure properties, occurrence and uses. Vch eds. Germany, 558p.

Cornell, R. M., Giovanoli, R., \& Schweitzer, W. (1990). Effect of crysteine and manganese on the crystallisation on iron crystalline iron (III), hydroxides Ph8. Clays minérals., 38, 21-28

Delvigne, J. (1970). Micromorphologie de l'altération des feldspaths et des minéraux-ferromagnésiens sous climat ferralitique. Collection ORSTOM. Fond documentaire N 29968.14p.

Deruelle, B., Moreau, C., Kambou, R., Lissom, J., Njonfang, E., Ghogomu, R. T., \& Nono, A. (1991). The Cameroon Line: A Review. In: A. B. Kampuzu and R. T. Lubal, Eds., Magmatism in Extensional Structural Settings, Springer-Verlag, Berlin: 274-327.

Dongmo, J. L. (1981). Les dynamismes Bamilékés. Tomes I, la maitrise de l'espace agraire. Yaoundé CEPER, 424.

Eno-Belinga, S. M. (1972). Altération des roches basaltiques et processus de bauxitisation de l'Adamaoua. Thèse de doctorat d'Etat, Univ.de Paris V ieme, 570p.

Eno-Belinga, S. M. (1984). Géologie du Cameroun, SOPECAM, Yaoundé, Cameroun, 307 p.

Fozing, E. M. (2009). Etude des amphibolites et des mylonites du Massif de Fomopéa. Thèse de Master, Université de Dschang, 88p.

Gallagher, P. (2014). Further High Grade Bauxite Results Drilling Program to Commence on the Birsok Project, Cameroon. Canyon Resources Limited report.10p.

Gastuche, M. C., \& Herbillon, A. (1962). Etude des gels d'alumine; cristallisation en milieu désionisé. Bull. Soc. Chim. Fr, 7, 1404-1412.

Graham, T., \& Eggleton, T. (2012). All pisolithic bauxite deposits are transported - Really? Australian Regolith and Clays Conference Mildura 7-10 February 2012. University of Canberra, Australian National University.4p.

Hieronymus, B. (1972) Etude minéralogique et géochimique des formations bauxitiques de l'Ouest Cameroun. Collection ORSTOM: 77-112.

Hieronymus, B. (1973). Bauxites latéritiques et bauxites: cas du contact forêt-savane du Sud-Est Cameroun, thèse d'État, Université de Yaoundé-1, 208p.

King, L. C. (1967). The Morphology of the Earth A Study and Synthesis of World, Scenery, Hafner Publishing Company, New York. 188p.

Kwékam, M. (2005). Genèse et évolution des granitoïdes calco-alcalin au cours de la tectonique panafricaine: le cas des massifs syn à tardi- tectoniques de l'ouest-cameroun (région de Dschang et Kékem). Thèse d'Etat, Université de Yaoundé I, 175 p.

Leprun, J. C. (1977). Géochimie de la surface et formes du relief IV. La dégradation des cuirasses ferrugineuses. Étude et importance du phénomène pédologique en Afrique de l'Ouest. Sci. Géol., Bull., 30(4), 265-273, Strasbourg.

Letouzey, R. (1985). Etude phytogéographique du Cameroun. Édition.p.Lechevelier.511p.

Lucas, Y., Kobilsek, B., \& Chauvel, A. (1989). Structure, genesis and present evolution of Amazonian bauxites 
developed on sediments. Travaux ICSOBA, 19, 81-94.

Maignien, R. (1980). Manuel Pour la Description des Sols sur le Terrain. Document ORSTOM, Paris, 112p.

Mc-Queen, K. G., \& Scott, K. M. (2008). Rock weathering and strcuture of the regolith. In Scott, K. M., \& Pain, C. F. (Eds.), Regolith science: 105-126. Dordrech, the Netherlands and Collingwood, Australia: springer science+Business media B.V. and Csiro publishing.

Melingui, A., Gwanfogbe, M., \& Ngoughia, J. (1989). Géographie du Cameroun. Edition CEPER. Yaounde.119p.

Momade, F. W. Y., \& Gawu, S. K. Y. (2009). Geochemical and mineralogical characteristics of lithomargic clay types from awaso bauxite deposit, Ghana: implications for possible industrial utilization. Journal of Science and Technology, 29(2), 11.

Momo, N. M., Tematio, P., \& Yemefack, M. (2012). Multi-Scale Organization of the Doumbouo-Fokoué Bauxites Ore Deposits (West Cameroon): Implication to the landscape Lowering. Open Journal of Geology, $14-24$.

Morin, S. (1980). Apport des images lansadts à la connaissance de la structure des hautes terres de l'Ouest-Cameroun. Rev de Geogr, 1(2), 181-196.

Munsell Soil Color. (1975). Charts. Macbeth. Division of kallmorge, corporation.2441 nord Calvert street Baltimore Maryland.21218.

Nesbitt, H. W., \& Young, G. M. (1982). Early Proterozoic climates and plate motions inferred from major element chemistry of lutites. Nature, 199, 715-717.

Njopwouo, D. (1984). Minéralogie et physico-chimie des argiles de Boumkoul et Balengou (Cameroun). Utilisation dans la polymérisation du styrène et dans le renforcement des caoutchoucs naturels. Thèse Doctorat d'Etat Univ.de Yaoundé I 300p.

Nkouathio, D. G., Kagou, D. A., Bardintzeff, J. M., Wandji, P., Bellon, H., \& Pouclet, A. (2008). Evolution of Volcanism in Graben and Horst Structures Along the Cenozoic Cameroon Line (Africa): Implications for Tectonic Evolution and Mantle Source Composition. Mineralogy and Petrology, 94, 287-303.

Nono, A., Njonfang, E., Djeuda, B., Tella, N., Tabue, G., \& Bouopda, J. F. (2001). Influence de la nature lithologique et des structures géologiques sur la dynamique et la qualité des eaux souterraines et des sources dans les hauts plateaux de l'Ouest-Cameroun. Journal of geosciences society of Cameroon, 106-107.

Ntep, P. (2009). Minerals Resources of the West Region Subdivisions. The Thematic Ores Resources Map of the Cameroon, Yaoundé.

Nyobé, J. B. (1987). Geology of the melan bauxite deposits western highlands republic of Cameroun. Annale de la faculté des sciences, Univ. de Yaoundé, 118-236.

Okamoto, G., Okura, T., \& Goto, K. (1957). Properties of silica in water. Geochim. Cosmoch. Acte, 12, 123-132.

Ruxton, B. P. (1968). Measures of the degree of chemical weathering of rocks. Journal of Geology, 76, 518-527.

Smith, G. D. (1986). The Guy Smith interviews. Rationale for concepts in soil Taxonomy, SMSS. Technical. Monograph, 11.SMSS, SCS, USDA, USA.

Tardy, Y. (1993). Pétrologie des latérites et des sols tropicaux. Edition Masson.Paris.460p

Tardy, Y., \& Nahon, D. (1985). Geochemistry of laterites, stability of Al-goethite, Al-hematite and Fe-kaolinite in bauxite and ferricretes: an approach to the mecanism of concentration formation. Am. J. Sci. 285, 865-903.

Temgoua, E., Bitom, D., Bilong, P, Lucas, Y., \& Pfeifer, H. R. (2002). « Démantèlement des Paysages Cuirassés Anciens en Zones Forestières Tropicales d'Afrique Centrale: Formation des Accumulations Ferrugineuses Actuelles en Bas de Versants » Compte Rendu Géoscience, 334(8), 537-543.

Tetsuhiro, W., Shinya, F., \& Takashi, K. (2010). Distribution and formation conditions of gibbsite in the upland soils of humid Asia: Japan, Thailand and Indonesia, 19th World Congress of Soil Science, Soil Solutions for a Changing World, 17-20.

Valeton, I. (1972). Bauxites development in Soils Sciences. Elsevier, 1, 226.

Valeton, I. (1981). Bauxites in peneplaned metamorphic and magmatic rocks, on detrital sediments and on karst topography. Their similarities and contrasts of genesis. In: International Seminar on Lateritisation Processes, 1 Trivandrum, 1981. Proceedings, Oxford and IBH Company, New-Delhi, 15-23. 
Weeksteen, G. (1957). Preliminary Report on the Fongo Tongo Bauxite ore Deposits. Report.

\section{Copyrights}

Copyright for this article is retained by the author(s), with first publication rights granted to the journal.

This is an open-access article distributed under the terms and conditions of the Creative Commons Attribution license (http://creativecommons.org/licenses/by/4.0/). 